\title{
Health-Risk Behaviour of Women and Men-Differences According to Partnership and Parenthood. Results of the German Health Update (GEDA) Survey 2009-2010
}

\author{
Elena von der Lippe and Petra Rattay
}

\section{Background}

Beginning life with a partner and becoming a parent are major life events for both men and women, bringing important changes. Diverse patterns of partnerships exist, and these exert differing effects on lifestyle. In making the transition to living with a partner, individuals may change existing behaviours or adopt new ones. Furthermore, the status of the relationship (e.g., cohabitation or marriage) may itself affect lifestyle. A marriage disruption may also lead to changes in certain behaviours. Similarly, the transition to parenthood contributes to changes in lifestyle and daily habits, including health behaviours. The number and age of the children in the household may also play a role.

These life changes may translate to a more responsible concern with lifestyle and health, and, according to Backett and Davison (1995), alterations in the evaluation of health behaviours. From the perspective of health behaviour, the transition to marriage exerts a positive influence - in marriage, an enhanced sense of obligation inhibits harmful behaviours and encourages healthy ones (Fuller 2010; Umberson 1987). Parenting similarly increases responsibility and greater self-regulation (Umberson 1987).

E. von der Lippe $(\square) \cdot$ P. Rattay

Robert Koch Institute, Berlin, Germany

e-mail: vonderLippeE@ rki.de

P. Rattay

e-mail: RattayP@rki.de

(C) The Author(s) 2018

G. Doblhammer and J. Gumà (eds.), A Demographic Perspective on Gender,

Family and Health in Europe, https://doi.org/10.1007/978-3-319-72356-3_10 


\section{Conceptual Framework}

Different mechanisms have been proposed for the link between family status and health behaviour. In the first, partnership and parenting positively influence health behaviour through social control and through social support (Brockmann and Klein 2004; Umberson 1987, 1992; Umberson et al. 2010). Social control in particular seems to be an important determinant of health behaviour, affecting health behaviours directly (e.g., sanctions for deviant behaviour, regulation, and physical intervention) and indirectly (e.g., internalisation of norms of healthful behaviour and facilitation of positive health behaviours) (Umberson 1987). There may also be mechanisms by which having a partner and living with children could lead to a decrease in healthy behaviour (e.g., stress caused by combined social roles, social and domestic responsibilities, increased demands on time, or discord in the relationship) (Brown et al. 2009; Eng et al. 2005; Hull et al. 2010; Nomaguchi and Bianchi 2004). A transition to divorce or widowhood could also be detrimental to health because of the loss of social control or social support provided by a partner. Furthermore, it is also noted that many associations are reciprocal (e.g., a stressful relationship may lead to heavy drinking that, in turn, further stresses the relationship).

Another explanation for the link between partnership and health behaviour is that the search for a partner is associated with specific health behaviours. The need to be attractive and to go to places where potential partners might be found may result in behaviours such as increased physical activity, dieting, higher alcohol consumption, and smoking (Rapp and Schneider 2014).

One interesting finding emerging from the research on family status and health behaviour is that the effects of marriage and parenting are different for men and women. Women are more likely to attempt to control the health behaviours of other family members than are men (Fuller 2010). Consequently, marriage is more likely to be associated with social control for men. Additionally, men engage in health-risk behaviours more often, and this may be a focus of social control in marriage (Umberson 1987). Interestingly, women more often report experiencing social control by a parent or a child (Fuller 2010) — it may be that for women, the experience of marriage as a source of social control is relatively diminished in the context of other agents of social control.

A final consideration is the socio-economic situation of women and men, which varies depending on living arrangements. Socio-economic status (SES) could be a mediator in the association of partnership and parenthood with health behaviour. For example, single parents often have a lower SES than do partnered parents, and this may contribute to a higher prevalence of health-risk behaviour. It cannot be assumed, however, that the relationships between partnership and parenthood and health behaviour can be explained entirely by socio-economic and occupational factors (Roos et al. 1998). In the same vein, SES could be a moderator, as SES and family status may interact and show cumulative adverse effects on health behaviour. 


\section{Current State of Research}

Much of the research on health-risk behaviour has focused on smoking, at-risk alcohol consumption, substance (drug) use, obesity, physical activity, and nutrition. As these behaviours are measured through diverse instruments, the comparison of research findings is not straightforward.

\section{Smoking}

Research on smoking has shown that married people have higher success in quitting smoking than do unmarried people (McDermott et al. 2004; Waldron and Lye 1989). The higher smoking cessation rate among married people is usually discussed in the context of the social support provided by marriage (Waldron and Lye 1989) or the development of a more responsible concern with lifestyle and health when living with a partner (Backett and Davison 1995).

The association of smoking cessation with parenthood has been mainly investigated in women. Women are most motivated to stop smoking during pregnancy because of concerns about the health of their baby (McDermott et al. 2004). Many women who plan to become pregnant will stop smoking before pregnancy, while others will quit upon learning they are pregnant (DiClemente et al. 2000). Smoking is also related to the age of the children in the household. Waldron and Lye (1989) found that mothers of preschoolers are less likely to be smokers than are women without children, possibly because of increased smoking cessation during pregnancy. Similarly, Umberson (1992) reported that, in both women and men, having adult children is associated with more cigarette smoking than is having children under the age of 16 years. Interestingly, according to DiClemente et al. (2000), the most influential factor for a postpartum relapse is having a partner who smokes.

The association of smoking cessation with parenthood has been less investigated in men. This is an important omission, given the concerns about the effects of second-hand smoke on fetal and child health (and call for health promotion interventions targeting tobacco consumption in men) (White et al. 2012). Nevertheless, parenthood and preparation for parenthood are to some extent also associated with spontaneous quitting in men (Brenner and Mielck 1993), as indicated by Bottorff et al. (2006), who found expectant and new fathers experienced new discomfort with their smoking (Bottorff et al. 2006).

\section{Alcohol Consumption}

The research on at-risk alcohol consumption has focused on the association between drinking behaviour and social roles (Hajema and Knibbe 1998; Kuntsche et al. 2009), among these, mainly the roles of parent, partner, and employee.

Kuntsche et al. (2009) reported that men who live with a partner have a lower risk of heavy drinking than do single men. Similarly, women in a 'traditional' role 
(i.e., partner and parent) have the lowest risk of alcohol consumption. Kuntsche et al. (2009) also found that the higher the number of social roles the individual holds, the stronger the protective effect of social role on at-risk alcohol consumption. There is the expectation that drinking should not interfere with the adequate performance of social roles. Therefore, the social control on drinking may be stronger among individuals who hold more social roles. Hajema and Knibbe (1998) reported that social controls, including sanctions, may influence drinking behaviour in those with new roles; however, this is not true in the reverse situation of job loss - a reduction of social control (or more leisure time) is not necessarily associated with an increase in drinking.

In addition to the influence of social roles, education seems equally important for at-risk alcohol consumption. Kuntsche et al. (2006) found that type of social welfare system and relative gender equity determines largely how education, employment, and family roles are associated with heavy drinking.

\section{Diet}

In general, women follow dietary recommendations more often than men (Abel et al. 1992; Anderson et al. 1994; Robert Koch Institute 2011). Additionally, both married men and women have a healthier diet than do their divorced counterparts (Roos et al. 1998), but the loss of a partner, through divorce or death, appears to influence the dietary habits of men more than those of women (Roos et al. 1998).

The transition to parenthood is generally believed to influence dietary behaviour (Bassett-Gunter et al. 2013; McIntyre and Rhodes 2009). For instance, many parents consume healthy foods in order to act as role models for their children (Bassett-Gunter et al. 2013). An earlier study (Roos et al. 1998) reported that parental status is a determinant of dietary behaviour in women but not in men; however more recently, this pattern has also been observed in men. Bassett-Gunter et al. (2013) found that both new and established fathers report greater intentions to eat healthily than do men without children.

Berge et al. (2011) reported that young adult mothers had poorer dietary intakes compared with women without children. The authors concluded that there may be conflicting factors influencing dietary behaviour in mothers: they may want to model good nutrition but at the same time, have less available time to eat healthily (Berge et al. 2011).

A difference was additionally found between first-time parents and established parents. Olson (2005) showed that first-time mothers make the most consistent positive changes in food choice behaviour, whereas, Bassett-Gunter et al. (2013) found that established mothers have lower intentions to eat healthily compared with new parents and nonparents. The authors concluded that having multiple children negatively affects the motivation of mothers to eat healthily.

It has been suggested that in attempting to understand dietary behaviours in women, a conceptual framework should include a focus on both structural position (educational level and employment status) and family status (partner and parental 
statuses), whereas in men, the focus should be on educational level and partner status (Roos et al. 1998). Furthermore, Roos et al. (1998) reported that the patterns of association between eating behaviour and family status/structural factors were similar in the various multivariate models that were tested.

\section{Physical Activity}

The research on physical activity with regard to marriage and family has usually been grounded on the theory of planned behaviour (Ajzen 1991). For instance, McIntyre and Rhodes (2009) concluded that in women, being physically active and continuing this lifestyle during the transition to motherhood is based on a perception of control, in terms of time, fatigue, social support, and child care. Elsewhere, barriers to physical activity for couples were found to be 'being too tired', 'lacking willpower', 'trouble in sticking to a routine', 'finding planning time', and additionally in women, a 'lack of companions' with whom to exercise (Burke et al. 1999).

Repeated studies have shown that being unmarried, both in men and women, is associated with higher levels of physical activity (Kaplan et al. 2001; Nomaguchi and Bianchi 2004; Umberson 1992); however, in one study using the same data but two different methods to evaluate the association between marriage and physical activity, the authors arrived at two contradictory results - one analysis yielded no association, and the other found that the transition from a single to a married state resulted in significant positive changes in physical activity (King et al. 1998).

Parenthood significantly influences physical activity in women and men. Having young children reduces sport and exercise activities in women (Sternfeld et al. 1999); most often, leisure-time activities are actually replaced by household activities, perhaps due to a change in roles (Bellows-Riecken and Rhodes 2008). Both in men and women, living with young children leads to higher household activity and less sitting time, with a stronger association when there are more children in the household (Candelaria et al. 2012). Nomaguchi and Bianchi (2004) also found that living with small children is associated with less exercise but that the number of children in the household does not influence the time spent in exercise. The explanation given for this negative association between having young children and lower physical activity is that caring for small children is physically and emotionally demanding and leaves parents with little time or energy to exercise (Berge et al. 2011). Notably, as children age, physical activity in mothers increases (Umberson 1992).

\section{The Social Context}

Most studies have been conducted in English-speaking countries and are reflective of those societies; as such, the findings may not be generalizable to countries with different social structures. Indeed, the association of partnership, parenthood, and health behaviour has been proposed to be closely connected to the social welfare system of a country (Kuntsche et al. 2006). Deriving from the classic typology of welfare states 
(Esping-Andersen 1990), three different family policy regimes can be distinguished in Europe (Gerlach 2008): The Nordic model of family policy focuses on the achievement of gender equity, high participation of women in the labour market, and high compatibility between working and family demands. In contrast, the Anglo-Saxon family policy regime emphasises the role of the market as the central provider of welfare services and is characterised by low social benefits for families (restricted to families in need) and high female employment rates. Finally, the continental European family policy regimes, to which the German regime belongs, are characterised by the promotion of 'traditional' families (i.e., consisting of working men and family-oriented women). In continental European countries, measures to balance work and family efforts between women and men and to increase the employment rate of women are less well established than in the Nordic model of family policy.

In Germany, family policy historically has relied mainly on monetary benefits and tax breaks (e.g., income splitting), which focus primarily on the material security of families. Over the past decade, German family policy has introduced paid parental allowance and promoted the growth of childcare facilities. Nevertheless, the German birth rate remains low and the employment rate of mothers is average compared with that of other European countries.

These differences in family policy may influence the association between family status and health behaviour and suggest that the existing research findings may not be easily generalised to the German context. Because of the paucity of German studies examining the association of the described health behaviours with partnership and parenthood, it was important to investigate these associations in the German population.

\section{Research Questions/Hypotheses}

Based on the theoretical background and the previous empirical research, we investigated the following research questions and related hypotheses:

1. Is there an association between health behaviour and either partner or parental status?

\section{Hypotheses:}

(a) Partnered persons and persons living with children display healthier behaviours than do individuals without a partner or without children, respectively (because of higher levels of social support and social control).

(b) Parents of preschool-aged children and/or a higher number of children show healthier behaviours than do parents of older children or lower number of children, respectively (because of higher levels of social control).

(c) Single parents display higher risk behaviour than do partnered parents (because of higher levels of stress and lower levels of social support).

2. Is the association between family status and health behaviour influenced by differences in SES and/or employment status? 


\section{Hypothesis:}

(d) The association between family status and health behaviour is mediated by the SES and the employment status.

3. Is the association between family status and health behaviour different in women and men?

\section{Hypotheses:}

(e) The association between partner status and health behaviour is stronger for men than for women (because of higher levels of social control through the partner).

(f) Women living with children display healthier behaviour than do men living with children (because of higher engagement in parenting, and therefore higher levels of obligations and social control).

\section{Methods}

\section{Data}

The analysis was conducted using data obtained from the German Health Update (GEDA) survey (Lange et al. 2015), an ongoing, national telephone survey of the health of the adult German population. The repeated cross-sectional GEDA surveys aim to provide current data on health and disease, determinants of health, and the use of health services, for use in national and European health reporting systems, health policy, and public health research (Lange et al. 2015).

For the current analysis, the data sets from the years 2009 and 2010 were merged. The fieldwork for GEDA 2009 was conducted between July 2008 and June 2009, and for GEDA 2010 between September 2009 and July 2010. The data were collected from German-speaking adults living in private households with a land-line connection (Robert Koch Institute 2011, 2012). Sampling involved a two-step process. First, random samples of telephone numbers from the German fixed-line network were generated using the Gabler-Häder method, which assured the inclusion of unregistered and unpublished telephone numbers (Gabler and Häder 1999). Second, the 'last birthday method' was applied for random selection of respondents within a contacted household - the adult household member with the last birthday was selected for the sample. Data collection employed computer-assisted telephone interviewing, and the interviews took approximately half an hour to complete on average. The GEDA study was approved by The Federal Commissioner for Data Protection and Freedom of Information, and verbal informed consent was obtained from all of the participants in advance. A total of 43,312 adults took part in the surveys (cooperation rates: GEDA $2009=51.2 \%$ and GEDA $2010=55.8 \%$ ).

In the present analysis, we included only men and women who were aged 18-45 at the time of the survey, resulting in a sample size of 20,717 (9070 men and 11,647 
women). After cleaning the data for missing information on partner and parental status, we were left with data from a final sample of 20,595 respondents.

\section{Measuring Instruments}

\section{Outcomes}

The data on tobacco consumption were obtained from the survey question 'Do you smoke regularly or occasionally'? The possible survey answer categories were: 'Yes, regularly', 'Yes, occasionally', 'No, not any more', and 'Never have smoked', and we dichotomised these, collapsing the categories 'regularly' and 'occasionally' into one category (smoking) and the rest in another (nonsmoking).

To define at-risk alcohol consumption, we used the Consumption subscale of the Alcohol Use Disorder Identification Test (AUDIT-C) (Bush et al. 1998). The AUDIT-C is a three-item alcohol screening tool consisting of the questions "How often do you have a drink containing alcohol?", "How many standard drinks containing alcohol do you have on a typical day?", and "How often do you have six or more drinks on one occasion?" The screen assigns test scores to one of three categories: 'never drinker', 'moderate drinker' or 'at-risk alcohol drinker' (Gual et al. 2002; Reinert and Allen 2007). We converted these to a binary variable indicating at-risk alcohol consumption (yes/no) by collapsing the categories 'never drinker' and 'moderate drinker'.

Survey data on fruit and vegetable consumption were used to indicate dietary behaviour. These data were obtained through a set of questions on the number of portions. One portion is defined as a handful of fruit or vegetables. Additionally, the consumption of pure fruit or vegetable juice is counted as maximum one portion consumption per day. This was based on the World Health Organization (WHO) '5-a-day' campaign, which recommends 'a minimum of $400 \mathrm{~g}$ of fruits and vegetables per day' (Food and Agriculture Organization 2004). In the current analysis, unhealthy diet was defined as the consumption of fewer than two portions of fruit and vegetables per day.

The data on physical activity were obtained through questions on the frequency (days per week) and duration of physical activity that was strenuous enough to induce sweating or breathlessness. We dichotomised the responses as 'high physical activity' or 'low physical activity', defining high physical activity as a physical activity for at least 30 min per day on five or more days per week (Robert Koch Institute 2011).

\section{Predictors}

For the purpose of the analysis of partnership, we categorised survey respondents as 'single' (defined as never married and living alone), 'married or cohabiting', or 
'divorced or widowed', collapsing the last category because of the low number of cases. We defined women and men as parents if they lived in the household with at least one child younger than 18 years and we did not differentiate between genetically related, adopted, or step children. We also included data on the number of the children living in the household ('none', 'one', 'two or more') and the age of the youngest child in the household (0-6, 7-10, 11-17 years).

\section{Mediators}

We also investigated the possible mediating effects of SES and employment status. SES was calculated using a scale based on level of education, household income, and professional status, with possible scores between 3 and 21 points (Lampert et al. 2013). Respondents with scores in the first quintile were categorised as 'low SES', those with scores in the second to fourth quintiles formed the group of 'middle SES', and those with scores in the highest quintile were categorised as 'high SES' (Lampert et al 2013). Employment status (self-defined) was categorised as 'employed full time', 'employed part time', or 'non-employed'.

\section{Control Variables}

Age (18-24; 25-34; 35-44 years), geographic region ('East Germany, including Berlin' or 'West Germany'), self-rated health ('good' or 'poor'), and health limitation ('not limited', 'limited but not severely', or 'severely limited') were selected as control variables in the regression analysis. Both self-rated health and health limitation have been identified as important health indicators in the Minimum European Health Module (EHEMU 2010) and were included in the regression analysis to control for potential health-driven behaviours.

\section{Data Analysis}

Logistic regression models were estimated to investigate the association of health-risk behaviour of both women and men with parenthood and partnership. In the first models, we included all respondents from the sample, comparing childless men and women with those who had children. We then included only individuals living with children, to investigate the possible association of health-risk behaviour with the number and age of the children in the household.

Stratifying by sex, we analysed the different outcomes and groups, comparing two models: In Model 1, the control variables were age, region, self-rated health, and health limitation. In Model 2, SES and employment status were additionally included as controls. The comparison between these two models allowed for an investigation of the possible mediating effects of SES and employment status on the association between family status and health behaviour. 
To investigate whether associations were significantly different for men and women, we calculated a third model (Model 3) for both sexes, including interaction terms. In the analysis of women and men living with and without children, interactions between sex and partner status, and sex and number of children were estimated. In the analysis of only individuals with children, the interactions between sex and partner status, sex and number of children in the household, and sex and age of the youngest child were estimated. The significance of the interactions was tested using the two-tailed Wald test with significance level at $p<0.05$.

The analyses used weighted data to correct for distributions according to age, sex, geographic region, and education (Robert Koch Institute 2012). All analyses were performed with the Stata/SE 13 statistical package (StataCorp, College Station, TX, USA) using the survey (svy) module.

The sample characteristics are shown in Table 1.

\section{Results}

As seen in Fig. 1, for both women and men, there were differences in health-risk behaviour depending on partner status. The prevalence of smoking was significantly higher in divorced and widowed than in single or married persons. Moreover, married women smoked less often than did single women. In men, however, there were no difference in smoking behaviour between single and the married individuals. Regarding at-risk alcohol consumption, the prevalence was significantly higher in single than in married or divorced/widowed men and women. Married persons showed the lowest prevalence of unhealthy diet; however, the differences were statistically significant only for women. Low physical activity was most often seen in single women, followed by married women; in men, low physical activity was seen least often in divorced/widowed persons, but the differences between the partnership groups were not significant.

Figure 2 shows the differences in health behaviour with respect to the number of children living in the household. There were no differences in the prevalence of current smoking between women and men living without or with only one child in the household, but a significantly lower prevalence was found for women and men living with two or more children. Men and women living without children in the household showed at-risk alcohol consumption more often than did those living with children. Men had an unhealthy diet more often than women, but in both men and women, an unhealthy diet was seen less often with an increasing number of children in the household, although the differences were only significant between men and women living without children and those living with two or more children. Finally, women without children reported low physical activity more often than women with children, regardless of the number of children in the household. In men, however, there were no differences in the prevalence of low physical activity with respect to number of children. 


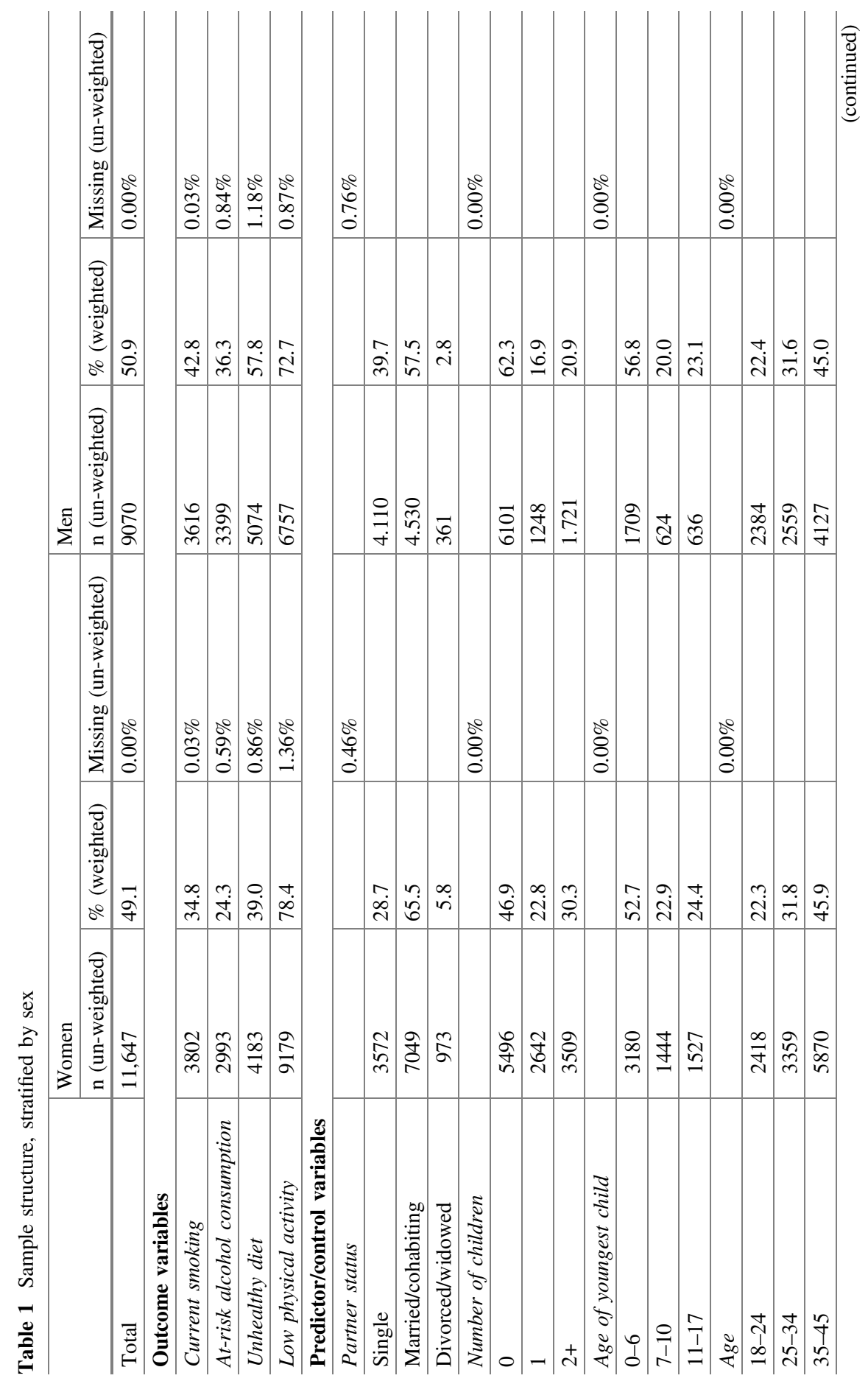




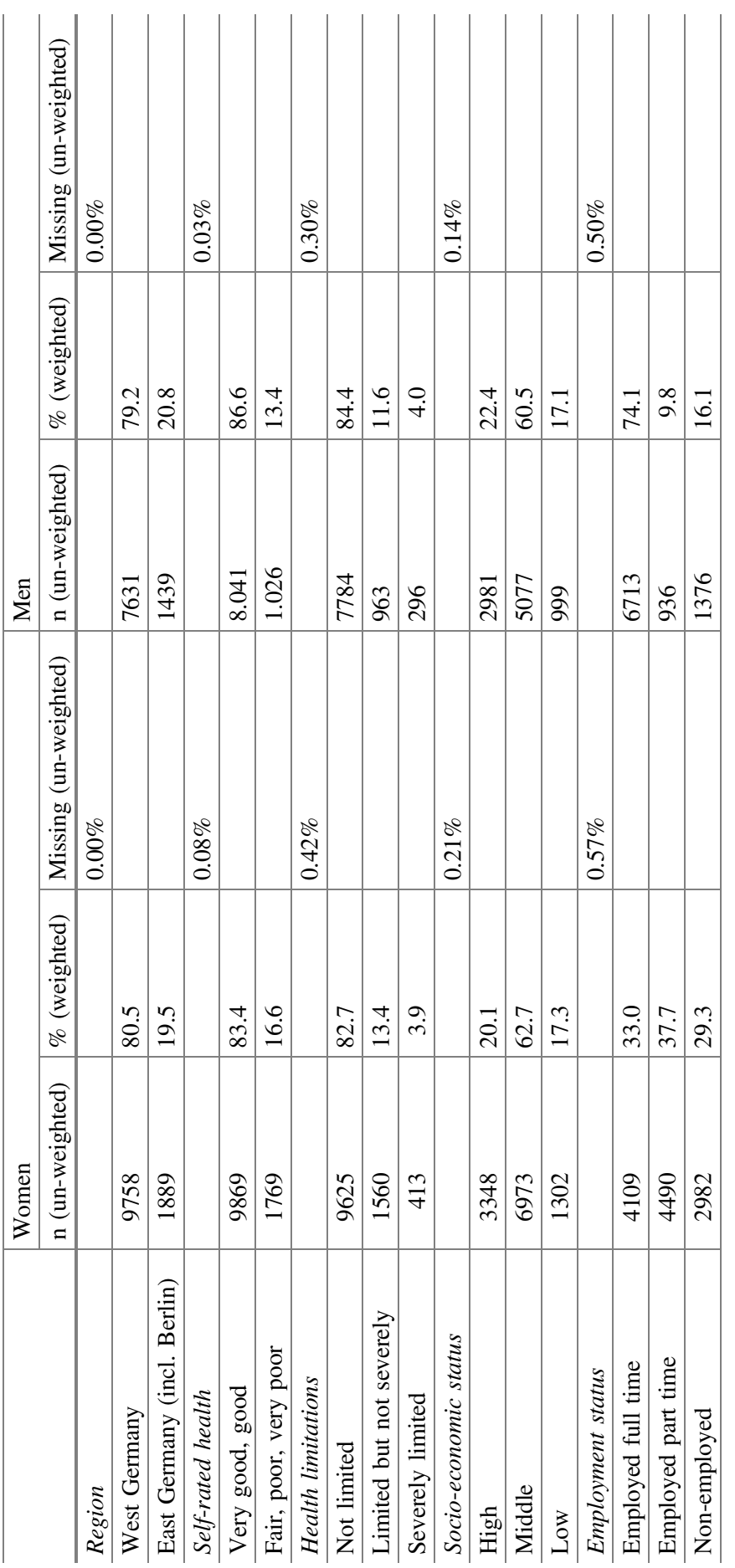




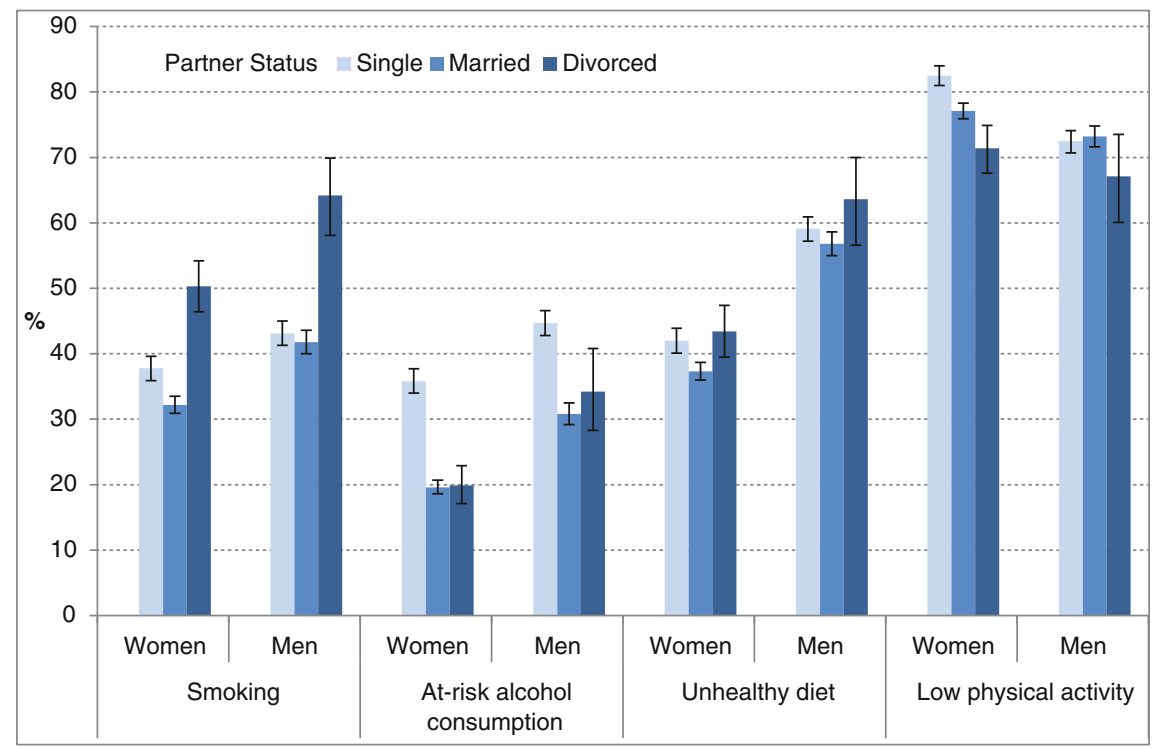

Fig. 1 Proportion of current smoking, at-risk alcohol consumption, unhealthy diet and low physical activity according to partner status, stratified by sex (incl. 95\%-CI)

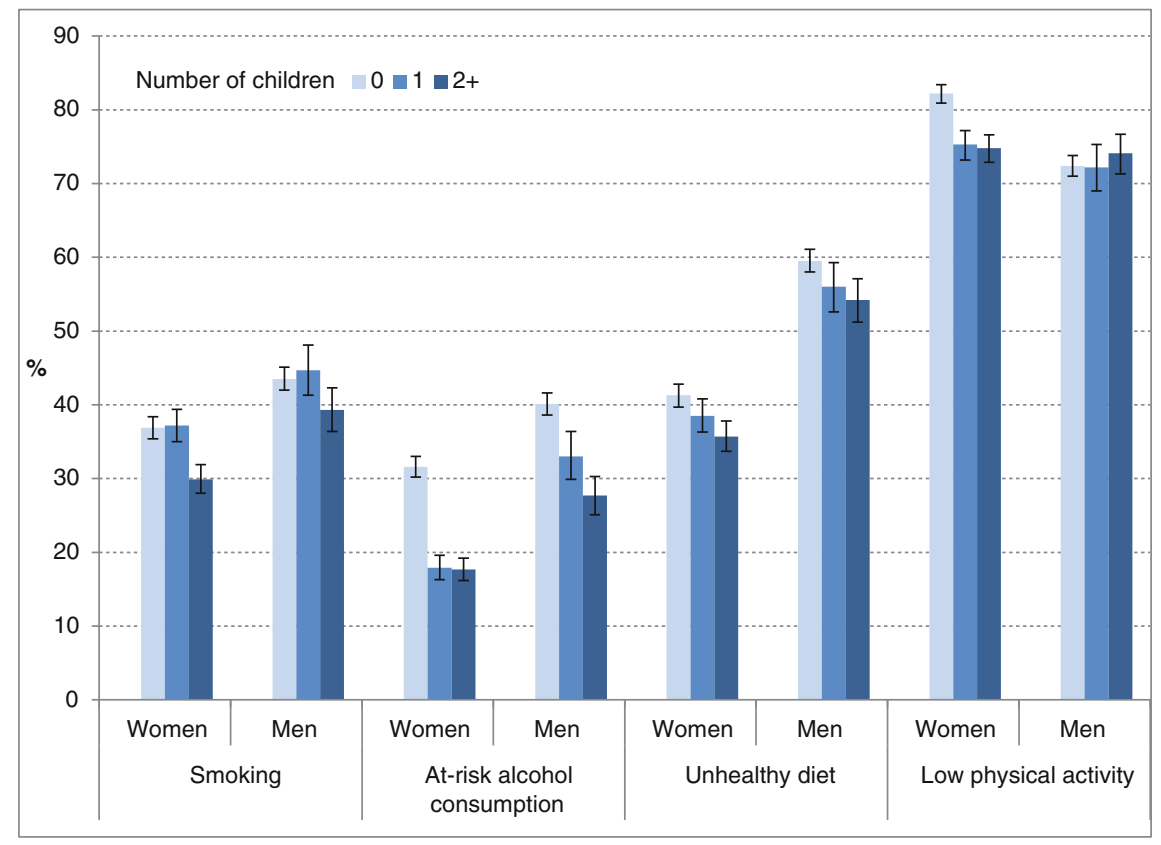

Fig. 2 Proportion of current smoking, at-risk alcohol consumption, unhealthy diet and low physical activity according to the number of children in the household, stratified by sex (incl. 95\%-CI) 


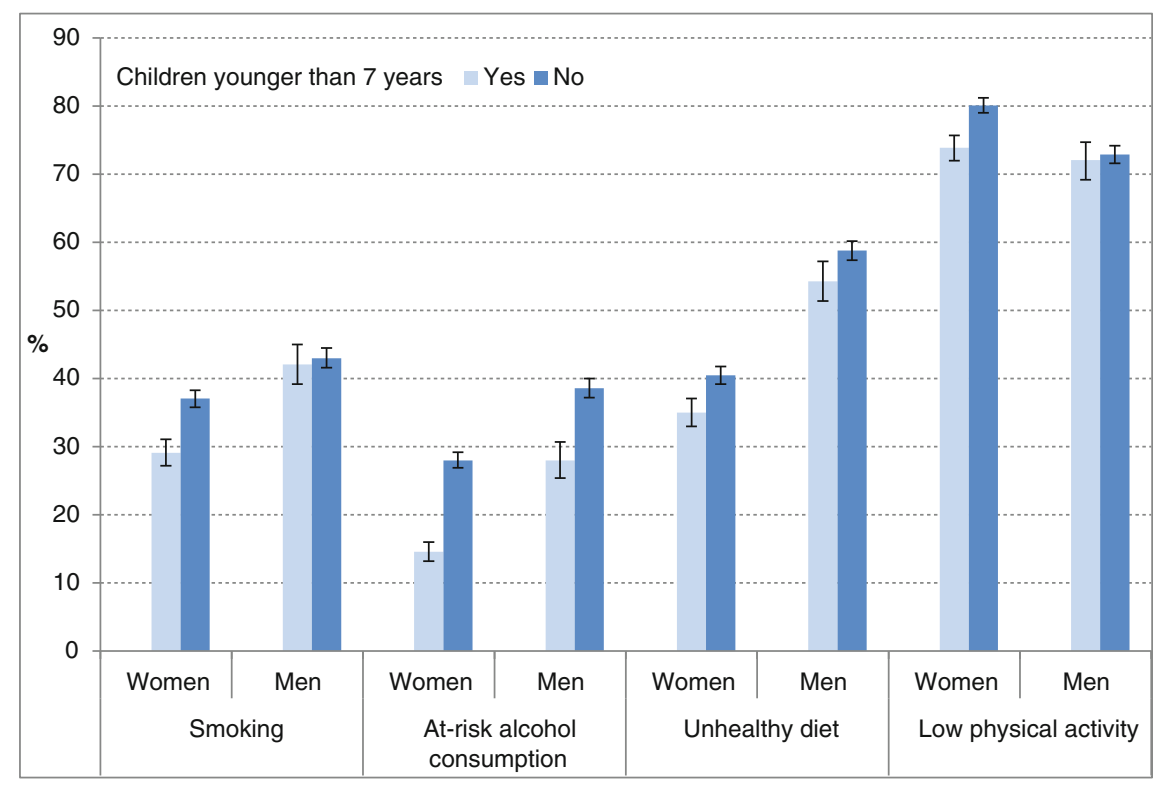

Fig. 3 Proportion of current smoking, at-risk alcohol consumption, unhealthy diet and low physical activity according to the age of the youngest child in the household, stratified by sex (incl. 95\%-CI)

Figure 3 presents health-risk behaviour in parents according to the age of the youngest child in the household. Compared with mothers of older children, mothers living with a child younger than 6 years showed a lower prevalence of all health-risk behaviours. In fathers, the same trend was seen for at-risk alcohol consumption and diet, but for smoking and physical activity, no differences were found according to the age of the youngest child.

The results of the regression analysis largely confirmed the descriptive results. With regard to smoking (Table 2), divorced women and men showed significantly higher risks of smoking, even after controlling for age, region, self-rated health, and health limitations (Model 1). The association of health behaviour with the number of children was also confirmed, with a significant reduction in smoking observed only in men and women living with two or more children. The inclusion of SES and employment status in the models (Model 1 vs. Model 2) changed only the relationship, in men, between smoking and living with two or more children, which achieved statistical significance. Finally, analysis of the interactions of partner status and children with sex (Model 3) showed there were no significant differences between women and men in the association of partner and parental status with smoking.

Regression analysis also confirmed the association between at-risk alcohol consumption and partner status found by the descriptive analysis (Table 3), but this was not fully true for the association between at-risk alcohol consumption and 
Table 2 Odds ratios (OR) for smoking in women and men, two models compared

\begin{tabular}{|c|c|c|c|c|c|c|c|c|}
\hline \multirow[b]{3}{*}{ Variable } & \multicolumn{4}{|l|}{ Women } & \multicolumn{4}{|l|}{ Men } \\
\hline & \multicolumn{2}{|l|}{ Model 1} & \multicolumn{2}{|l|}{ Model 2} & \multicolumn{2}{|l|}{ Model 1} & \multicolumn{2}{|l|}{ Model 2} \\
\hline & OR & $\begin{array}{l}95 \% \\
\text { CI }\end{array}$ & OR & $\begin{array}{l}95 \% \\
\text { CI }\end{array}$ & OR & $\begin{array}{l}95 \% \\
\text { CI }\end{array}$ & OR & $\begin{array}{l}95 \% \\
\mathrm{CI}\end{array}$ \\
\hline \multicolumn{9}{|c|}{ Partner status } \\
\hline Single & $1.24 * *$ & $\begin{array}{l}1.08- \\
1.42\end{array}$ & $1.17 *$ & $\begin{array}{l}1.02- \\
1.34\end{array}$ & 1.07 & $\begin{array}{l}0.92- \\
1.25\end{array}$ & 1.07 & $\begin{array}{l}0.91- \\
1.25\end{array}$ \\
\hline Married & 1 & & 1 & & 1 & & 1 & \\
\hline Divorced & $2.05 * * *$ & $\begin{array}{l}1.72- \\
2.43\end{array}$ & $1.75 * * *$ & $\begin{array}{l}1.47- \\
2.10\end{array}$ & $2.51 * * *$ & $\begin{array}{l}1.90- \\
3.31\end{array}$ & $2.32 * * *$ & $\begin{array}{l}1.76- \\
3.06\end{array}$ \\
\hline \multicolumn{9}{|c|}{ Number of children } \\
\hline 0 & 1 & & 1 & & 1 & & 1 & \\
\hline 1 & 1.00 & $\begin{array}{l}0.87- \\
1.15\end{array}$ & 1.04 & $\begin{array}{l}0.90- \\
1.20\end{array}$ & 1.06 & $\begin{array}{l}0.88- \\
1.27\end{array}$ & 0.95 & $\begin{array}{l}0.80- \\
1.15\end{array}$ \\
\hline $2+$ & $0.76 * * *$ & $\begin{array}{l}0.66- \\
0.88\end{array}$ & $0.79 * *$ & $\begin{array}{l}0.67- \\
0.92\end{array}$ & 0.87 & $\begin{array}{l}0.73- \\
1.03\end{array}$ & $0.77 * *$ & $\begin{array}{l}0.64- \\
0.92\end{array}$ \\
\hline
\end{tabular}

Model 3 (both sexes): interactions

\begin{tabular}{l|l}
\hline $\begin{array}{l}\text { Partner status } \\
\text { \# sex }\end{array}$ & -value 0.103 \\
\hline $\begin{array}{l}\text { Children \# } \\
\text { sex }\end{array}$ & $p$-value 0.733 \\
\hline
\end{tabular}

Significance level of interactions of partner status and children with sex

OR presented from the models without interactions. Model 1 controlled for age, region, SRH, and health limitations. Model 2 and 3 controlled for age, region, SRH, health limitations, SES, and employment status. $* p<0.05 ; * * p<0.01 ; * * p<0.001$

number of children in the household - in men, the observed differences lost significance. The inclusion of SES and employment status in the model (Model 1 vs. Model 2) did not substantially change the results. Analysis of the interaction between sex and number of children revealed there were significant differences between men and women in the association of number of children with at-risk alcohol consumption (Model 3), but no significant differences between women and men in the association of partner status with at-risk alcohol consumption (Model 3).

With regard to an unhealthy diet (Table 4), Model 1 showed a significantly higher odds ratio for divorced and widowed women in comparison with married women but not single women (for men, there was a similar tendency, but the results were not significant). After including SES and employment status in the model (Model 1 vs. Model 2), the odds ratio for divorced women lost significance as well. Thus, in women, the association of diet with partner status is to some extent mediated by SES.

After adjusting for age, region, self-rated health, and health limitation, both women and men living with at least two children had a healthier diet than did childless women and men (Model 1); however, for men, the findings changed after inclusion of SES and employment status in the analysis (Model 2). After adjusting 
Table 3 Odds ratios (OR) for at-risk alcohol consumption in women and men, two models compared

\begin{tabular}{|c|c|c|c|c|c|c|c|c|}
\hline \multirow[b]{3}{*}{ Variable } & \multicolumn{4}{|l|}{ Women } & \multicolumn{4}{|l|}{ Men } \\
\hline & \multicolumn{2}{|l|}{ Model 1} & \multicolumn{2}{|l|}{ Model 2} & \multicolumn{2}{|l|}{ Model 1} & \multicolumn{2}{|l|}{ Model 2} \\
\hline & OR & $\begin{array}{l}95 \% \\
\text { CI }\end{array}$ & OR & $\begin{array}{l}95 \% \\
\text { CI }\end{array}$ & OR & $\begin{array}{l}95 \% \\
\text { CI }\end{array}$ & OR & $\begin{array}{l}95 \% \\
\text { CI }\end{array}$ \\
\hline \multicolumn{9}{|c|}{ Partner status } \\
\hline Single & $1.49 * * *$ & $\begin{array}{l}1.30- \\
1.72\end{array}$ & $1.54 * * *$ & $\begin{array}{l}1.34- \\
1.78\end{array}$ & $1.42 * * *$ & $\begin{array}{l}1.21- \\
1.65\end{array}$ & $1.40 * * *$ & $\begin{array}{l}1.20- \\
1.64\end{array}$ \\
\hline Married & 1 & & 1 & & 1 & & 1 & \\
\hline Divorced & 1.05 & $\begin{array}{l}0.86- \\
1.28 \\
\end{array}$ & 1.12 & $\begin{array}{l}0.91- \\
1.37 \\
\end{array}$ & 1.21 & $\begin{array}{l}0.90- \\
1.64 \\
\end{array}$ & 1.24 & $\begin{array}{l}0.91- \\
1.67\end{array}$ \\
\hline \multicolumn{9}{|c|}{ Number of children } \\
\hline 0 & 1 & & 1 & & 1 & & 1 & \\
\hline 1 & $0.63 * * *$ & $\begin{array}{l}0.54- \\
0.74\end{array}$ & $0.66^{* * *}$ & $\begin{array}{l}0.56- \\
0.77\end{array}$ & 1.04 & $\begin{array}{l}0.87- \\
1.26\end{array}$ & 1.05 & $\begin{array}{l}0.87- \\
1.27\end{array}$ \\
\hline $2+$ & $0.64 * * *$ & $\begin{array}{l}0.55- \\
0.75\end{array}$ & $0.68 * * *$ & $\begin{array}{l}0.57- \\
0.80\end{array}$ & 0.86 & $\begin{array}{l}0.71- \\
1.02\end{array}$ & 0.88 & $\begin{array}{l}0.73- \\
1.05\end{array}$ \\
\hline
\end{tabular}

Model 3 (both sexes): interactions

\begin{tabular}{l|l}
\hline $\begin{array}{l}\text { Partner status } \\
\text { \# sex }\end{array}$ & $p$-value 0.824 \\
\hline $\begin{array}{l}\text { Children \# } \\
\text { sex }\end{array}$ & p-value $<0.001$ \\
\hline
\end{tabular}

Significance level of interactions of partner status and children with sex

OR presented from the models without interactions. Model 1 controlled for age, region, SRH, and health limitations. Model 2 and 3 controlled for age, region, SRH, health limitations, SES, and employment status. $* p<0.05 ; * p<0.01 ; * * * p<0.001$

for these, living with one child also appeared to be significant and thus, for men, a healthy diet was significantly associated with living with children irrespective of their number. Despite these apparent differences, inclusion of interaction terms in the analysis (Model 3) did not show a significant difference between men and women with regard to the association of diet with partner status and number of children.

After adjusting for age, region, self-rated health, and health limitation, the odds ratios for low physical activity (Table 5) were still lower for divorced and widowed than for married women and men (Model 1); however, in the fully adjusted model (Model 2), there were no longer any differences according to partner status.

The association with the number of children found in the descriptive results was also confirmed in the regression analysis: women with children showed higher odds of physical activity than did those without children, and this remained stable even after adjusting for SES and employment status (Model 2). For men, there were no significant associations with number of children after analysis with either Model 1 or Model 2. The analysis of sex variances showed significant differences between women and men in the association of number of children in the household with physical activity (Model 3). 
Table 4 Odds ratios (OR) for unhealthy diet in women and men, two models compared

\begin{tabular}{|c|c|c|c|c|c|c|c|c|}
\hline \multirow[b]{3}{*}{ Variable } & \multicolumn{4}{|l|}{ Women } & \multicolumn{4}{|c|}{ Men } \\
\hline & \multicolumn{2}{|c|}{ Model 1} & \multicolumn{2}{|c|}{ Model 2} & \multicolumn{2}{|c|}{ Model 1} & \multicolumn{2}{|l|}{ Model 2} \\
\hline & OR & $\begin{array}{l}95 \% \\
\text { CI }\end{array}$ & OR & $\begin{array}{l}95 \% \\
\text { CI }\end{array}$ & $\mathrm{OR}$ & $\begin{array}{l}95 \% \\
\text { CI }\end{array}$ & OR & $\begin{array}{l}95 \% \\
\text { CI }\end{array}$ \\
\hline \multicolumn{9}{|c|}{ Partner status } \\
\hline Single & 1.04 & $\begin{array}{l}0.91- \\
1.18\end{array}$ & 0.96 & $\begin{array}{l}0.84- \\
1.10\end{array}$ & 0.98 & $\begin{array}{l}0.84- \\
1.15\end{array}$ & 0.97 & $\begin{array}{l}0.83- \\
1.14\end{array}$ \\
\hline Married & 1 & & 1 & & 1 & & 1 & \\
\hline Divorced & $1.29 * *$ & $\begin{array}{l}1.08- \\
1.53\end{array}$ & 1.07 & $\begin{array}{l}0.89- \\
1.27\end{array}$ & 1.20 & $\begin{array}{l}0.88- \\
1.64\end{array}$ & 1.13 & $\begin{array}{l}0.82- \\
1.57\end{array}$ \\
\hline \multicolumn{9}{|c|}{ Number of children } \\
\hline 0 & 1 & & 1 & & 1 & & 1 & \\
\hline 1 & 0.93 & $\begin{array}{l}0.82- \\
1.07\end{array}$ & 0.92 & $\begin{array}{l}0.80- \\
1.06\end{array}$ & 0.85 & $\begin{array}{l}0.71- \\
1.01\end{array}$ & $0.78 * *$ & $\begin{array}{l}0.65- \\
0.93\end{array}$ \\
\hline $2+$ & $0.83 * *$ & $\begin{array}{l}0.72- \\
0.95\end{array}$ & $0.79 * *$ & $\begin{array}{l}0.68- \\
0.92\end{array}$ & $0.78 * *$ & $\begin{array}{l}0.66- \\
0.93\end{array}$ & $0.73 * * *$ & $\begin{array}{l}0.61- \\
0.86\end{array}$ \\
\hline
\end{tabular}

Model 3 (both sexes): interactions

\begin{tabular}{l|l}
\hline $\begin{array}{l}\text { Partner } \\
\text { status \# } \\
\text { sex }\end{array}$ & $p$-value 0.555 \\
\hline $\begin{array}{l}\text { Children } \\
\text { \# sex }\end{array}$ & p-value 0.187 \\
\hline
\end{tabular}

Significance level of interactions of partner status and children with sex

OR presented from the models without interactions. Model 1 controlled for age, region, SRH, and health limitations. Model 2 and 3 controlled for age, region, SRH, health limitations, SES, and employment status. $* p<0.05 ; * * p<0.01 ; * * *<0.001$

A further step in the analysis was to narrow the study to only men and women living with children. Here, we included data on the age of the youngest child in the household as well as the number of children.

With respect to tobacco consumption (Table 6), the results show that single mothers had very high odds of smoking compared with their married counterparts; divorced mothers also had higher odds, although not as high as those of single mothers. Divorced fathers had the highest odds of smoking.

Mothers with two children had significantly lower odds of smoking compared with mothers with one child; interestingly, no significant difference was found for mothers with three or more children, although the tendency was similar to that of mothers with two children. For fathers, no significant association was found between the number of children and smoking. Living with children aged 0-6 years showed lower odds of smoking in mothers, but no significant differences were found in fathers. We also did not find mediating effects of SES or employment status on the association between smoking with partner and parental status (there were no changes in the significance levels between Model 1 and Model 2). An analysis of the interaction terms showed there were differences between mothers 
Table 5 Odds ratios (OR) for low physical activity in women and men, two models compared

\begin{tabular}{|c|c|c|c|c|c|c|c|c|}
\hline \multirow[b]{3}{*}{ Variable } & \multicolumn{4}{|l|}{ Women } & \multicolumn{4}{|l|}{ Men } \\
\hline & \multicolumn{2}{|c|}{ Model 1} & \multicolumn{2}{|c|}{ Model 2} & \multicolumn{2}{|c|}{ Model 1} & \multicolumn{2}{|c|}{ Model 2} \\
\hline & OR & $\begin{array}{l}95 \% \\
\text { CI }\end{array}$ & OR & $\begin{array}{l}95 \% \\
\text { CI }\end{array}$ & OR & $\begin{array}{l}95 \% \\
\text { CI }\end{array}$ & OR & $\begin{array}{l}95 \% \\
\text { CI }\end{array}$ \\
\hline \multicolumn{9}{|c|}{ Partner status } \\
\hline Single & 1.13 & $\begin{array}{l}0.96- \\
1.34\end{array}$ & 1.17 & $\begin{array}{l}0.99- \\
1.38\end{array}$ & 1.16 & $\begin{array}{l}0.97- \\
1.38 \\
\end{array}$ & 1.12 & $\begin{array}{l}0.93- \\
1.34\end{array}$ \\
\hline Married & 1 & & 1 & & 1 & & 1 & \\
\hline Divorced & $0.74 * *$ & $\begin{array}{l}0.61- \\
0.90\end{array}$ & 0.82 & $\begin{array}{l}0.67- \\
1.00\end{array}$ & $0.71^{*}$ & $\begin{array}{l}0.52- \\
0.99\end{array}$ & 0.76 & $\begin{array}{l}0.55- \\
1.05\end{array}$ \\
\hline
\end{tabular}

Number of children

\begin{tabular}{l|l|l|l|l|l|l|l|l}
\hline 0 & 1 & & 1 & & 1 & & 1 & \\
\hline 1 & $0.69 * * *$ & $0.58-$ & $0.66 * * *$ & $0.55-$ & 0.95 & $0.78-$ & 1.05 & $0.85-$ \\
& & 0.81 & & 0.79 & & 1.16 & & 1.29 \\
\hline $2+$ & $0.65 * * *$ & $\begin{array}{l}0.55- \\
0.90\end{array}$ & $0.62 * * *$ & $0.52-$ & 0.99 & $0.81-$ & 1.10 & $0.90-$ \\
& & 0.75 & & 1.20 & & 1.35 \\
\hline
\end{tabular}

Model 3 (both sexes): interactions

\begin{tabular}{l|l}
\hline $\begin{array}{l}\text { Partner } \\
\text { status \# sex }\end{array}$ & -value 0.308 \\
\hline $\begin{array}{l}\text { Children \# } \\
\text { sex }\end{array}$ & p-value $<0.001$ \\
\hline
\end{tabular}

Significance level of interactions of partner status and children with sex

OR presented from the models without interactions. Model 1 controlled for age, region, SRH, and health limitations. Model 2 and 3 controlled for age, region, SRH, health limitations, SES, and employment status. $* p<0.05 ; * * p<0.01 ; * * p<0.001$

and fathers in the association of partner status with smoking (Model 3). Sex differences were also observed in the association of age of the youngest child with smoking.

At-risk alcohol consumption was strongly associated with partner status among mothers, with single mothers showing the highest odds (Table 7). No significant differences were found for fathers, despite a visible trend of higher at-risk alcohol consumption in single fathers. We did not find any differences in at-risk alcohol consumption according to the number of the children in the household in either mothers or fathers; however, the age of the youngest child showed significant association in mothers. As with smoking, we did not find a mediating effect of SES or employment status on the relationship between at-risk alcohol consumption and family characteristics (no differences between Model 1 and Model 2). Furthermore, there was no significant difference between mothers and fathers in the association of at-risk alcohol consumption with partner status, number of children, or age of the youngest child (Model 3).

With regard to unhealthy diet (Table 8), in the fully adjusted model (Model 2), we did not find differences according to partner status or number of children in the household, for both mothers and fathers; however, mothers living with children 


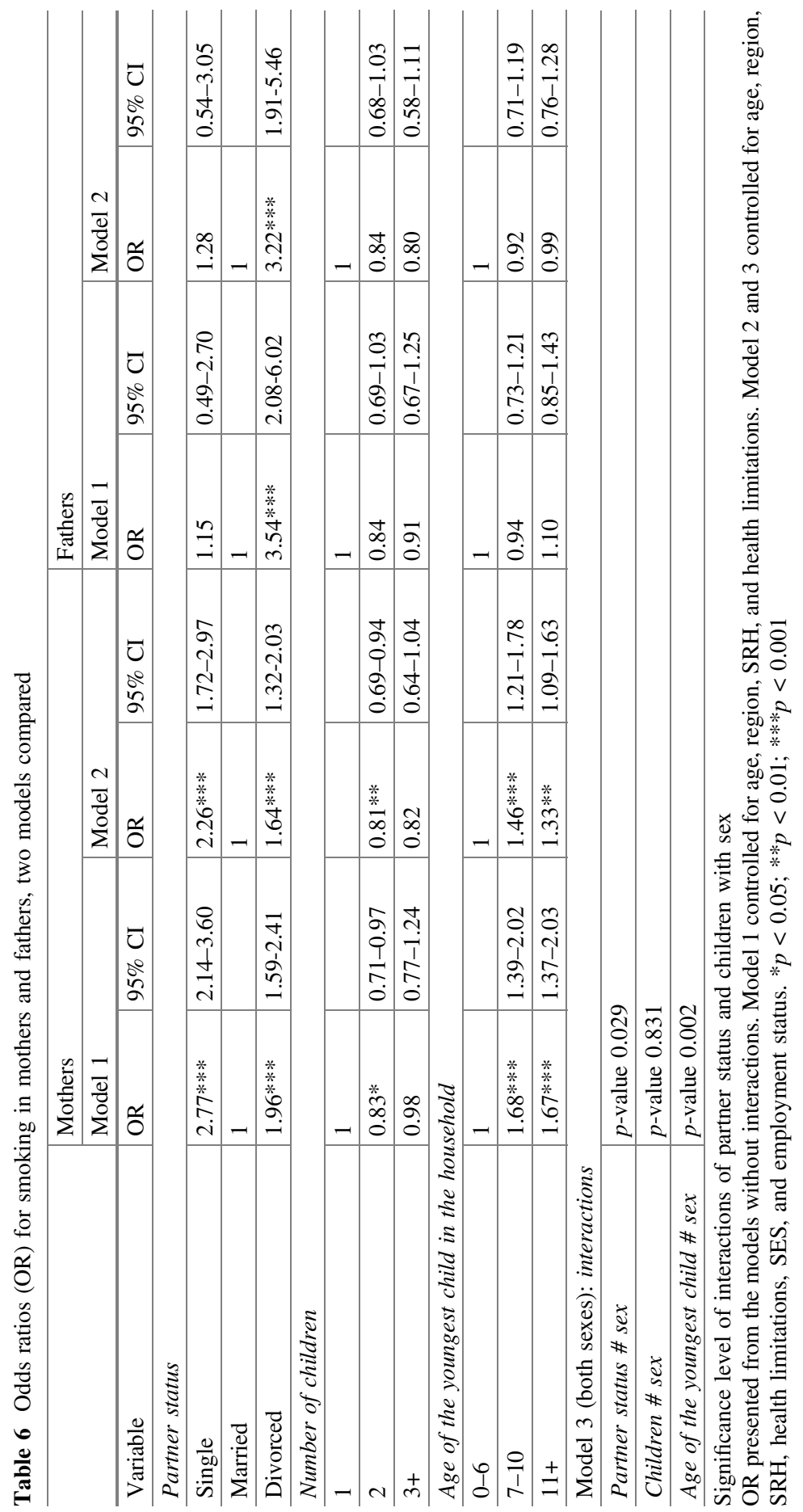


Table 7 Odds ratios (OR) for at-risk alcohol consumption in mothers and fathers, two models compared

\begin{tabular}{|c|c|c|c|c|c|c|c|c|}
\hline \multirow[b]{3}{*}{ Variable } & \multicolumn{4}{|c|}{ Mothers } & \multicolumn{4}{|c|}{ Fathers } \\
\hline & \multicolumn{2}{|c|}{ Model 1} & \multicolumn{2}{|l|}{ Model 2} & \multicolumn{2}{|c|}{ Model 1} & \multicolumn{2}{|c|}{ Model 2} \\
\hline & OR & $\begin{array}{l}95 \% \\
\text { CI }\end{array}$ & OR & $\begin{array}{l}95 \% \\
\text { CI }\end{array}$ & OR & $\begin{array}{l}95 \% \\
\text { CI }\end{array}$ & OR & $\begin{array}{l}95 \% \\
\text { CI }\end{array}$ \\
\hline \multicolumn{9}{|c|}{ Partner status } \\
\hline Single & $1.68 * *$ & $\begin{array}{l}1.25- \\
2.27\end{array}$ & $1.84 * * *$ & $\begin{array}{l}1.35- \\
2.50\end{array}$ & 1.53 & $\begin{array}{l}0.60- \\
3.88\end{array}$ & 1.51 & $\begin{array}{l}0.60- \\
3.80 \\
\end{array}$ \\
\hline Married & 1 & & 1 & & 1 & & 1 & \\
\hline Divorced & 1.11 & $\begin{array}{l}0.88- \\
1.41 \\
\end{array}$ & 1.22 & $\begin{array}{l}0.96- \\
1.56\end{array}$ & 0.71 & $\begin{array}{l}0.38- \\
1.32 \\
\end{array}$ & 0.73 & $\begin{array}{l}0.39- \\
1.36 \\
\end{array}$ \\
\hline \multicolumn{9}{|c|}{ Number of children } \\
\hline 1 & 1 & & 1 & & 1 & & 1 & \\
\hline 2 & 1.12 & $\begin{array}{l}0.95- \\
1.32\end{array}$ & 1.15 & $\begin{array}{l}0.97- \\
1.36\end{array}$ & 0.87 & $\begin{array}{l}0.70- \\
1.07\end{array}$ & 0.88 & $\begin{array}{l}0.71- \\
1.09\end{array}$ \\
\hline $3+$ & 0.89 & $\begin{array}{l}0.68- \\
1.17\end{array}$ & 1.02 & $\begin{array}{l}0.78- \\
1.33\end{array}$ & 0.75 & $\begin{array}{l}0.54- \\
1.08\end{array}$ & 0.79 & $\begin{array}{l}0.56- \\
1.11\end{array}$ \\
\hline \multicolumn{9}{|c|}{ Age of the youngest child in the household } \\
\hline $0-6$ & 1 & & 1 & & 1 & & 1 & \\
\hline $7-10$ & $1.34 * *$ & $\begin{array}{l}1.09- \\
1.65\end{array}$ & $1.36 * *$ & $\begin{array}{l}1.11- \\
1.67\end{array}$ & 1.06 & $\begin{array}{l}0.82- \\
1.37\end{array}$ & 1.06 & $\begin{array}{l}0.82- \\
1.38\end{array}$ \\
\hline $11+$ & $1.38^{* * *}$ & $\begin{array}{l}1.12- \\
1.70\end{array}$ & $1.47 * *$ & $\begin{array}{l}1.19- \\
1.83\end{array}$ & 1.19 & $\begin{array}{l}0.92- \\
1.55\end{array}$ & 1.18 & $\begin{array}{l}0.90 \\
1.53\end{array}$ \\
\hline
\end{tabular}

Model 3 (both sexes): interactions

\begin{tabular}{l|l}
\hline Partner status \# sex & $p$-value 0.380 \\
\hline Children \# sex & $p$-value 0.121 \\
\hline $\begin{array}{l}\text { Age of the youngest } \\
\text { child \# sex }\end{array}$ & $p$-value 0.300 \\
\hline Sigit
\end{tabular}

Significance level of interactions of partner status and children with sex

OR presented from the models without interactions. Model 1 controlled for age, region, SRH, and health limitations. Model 2 and 3 controlled for age, region, SRH, health limitations, SES, and employment status. $* p<0.05 ; * * p<0.01 ; * * * p<0.001$

older than 10 years had higher odds of unhealthy diet. The comparison between Model 1 and Model 2 showed that SES and employment status mediated the relationship between nutrition and living with children aged 7-10 years as well as, in women, the association of nutrition and being single. Analysis of the interaction terms showed no significant differences between mothers and fathers in the association of partner and parental status with an unhealthy diet (Model 3).

The fully adjusted models for physical activity (Table 9) showed that divorced mothers had high odds of physical activity, as did mothers living with at least three children. For fathers, no differences in physical activity were found according to partner status or number of children. The age of the youngest child was not significantly associated with physical activity in mothers. Adjustment for SES and 
Table 8 Odds ratios (OR) for unhealthy diet in mothers and fathers, two models compared

\begin{tabular}{|c|c|c|c|c|c|c|c|c|}
\hline \multirow[b]{3}{*}{ Variable } & \multicolumn{4}{|l|}{ Mothers } & \multicolumn{4}{|c|}{ Fathers } \\
\hline & \multicolumn{2}{|l|}{ Model 1} & \multicolumn{2}{|c|}{ Model 2} & \multicolumn{2}{|c|}{ Model 1} & \multicolumn{2}{|c|}{ Model 2} \\
\hline & OR & $\begin{array}{l}95 \% \\
\mathrm{CI}\end{array}$ & OR & $\begin{array}{l}95 \% \\
\mathrm{CI}\end{array}$ & OR & $\begin{array}{l}95 \% \\
\mathrm{CI}\end{array}$ & OR & $\begin{array}{l}95 \% \\
\mathrm{CI}\end{array}$ \\
\hline \multicolumn{9}{|l|}{ Partner status } \\
\hline Single & $1.50 * *$ & $\begin{array}{l}1.15- \\
1.95\end{array}$ & 1.25 & $\begin{array}{l}0.95- \\
1.65\end{array}$ & 0.57 & $\begin{array}{l}0.25- \\
1.31\end{array}$ & 0.63 & $\begin{array}{l}0.27- \\
1.47\end{array}$ \\
\hline Married & 1 & & 1 & & 1 & & 1 & \\
\hline Divorced & 1.16 & $\begin{array}{l}0.94- \\
1.43\end{array}$ & 0.97 & $\begin{array}{l}0.78- \\
1.20\end{array}$ & 1.24 & $\begin{array}{l}0.68- \\
2.29\end{array}$ & 1.29 & \begin{tabular}{|l}
$0.68-$ \\
2.44
\end{tabular} \\
\hline \multicolumn{9}{|c|}{ Number of children } \\
\hline 1 & 1 & & 1 & & 1 & & 1 & \\
\hline 2 & 0.94 & $\begin{array}{l}0.81- \\
1.08\end{array}$ & 0.89 & $\begin{array}{l}0.77- \\
1.03 \\
\end{array}$ & 0.96 & $\begin{array}{l}0.79- \\
1.17\end{array}$ & 0.98 & $\begin{array}{ll}0.80- \\
1.20 \\
\end{array}$ \\
\hline $3+$ & 1.15 & $\begin{array}{l}0.92- \\
1.44\end{array}$ & 0.93 & $\begin{array}{l}0.74- \\
1.17\end{array}$ & 0.96 & $\begin{array}{l}0.71- \\
1.30\end{array}$ & 0.92 & $\begin{array}{l}0.67- \\
1.24\end{array}$ \\
\hline \multicolumn{9}{|c|}{ Age of the youngest child in the household } \\
\hline $0-6$ & 1 & & 1 & & 1 & & 1 & \\
\hline $7-10$ & $1.23 *$ & $\begin{array}{l}1.03- \\
1.47\end{array}$ & 1.06 & $\begin{array}{l}0.89- \\
1.27\end{array}$ & 0.95 & $\begin{array}{l}0.75- \\
1.20\end{array}$ & 0.93 & $\begin{array}{l}0.73- \\
1.18 \\
\end{array}$ \\
\hline $11+$ & $1.52 * * *$ & $\begin{array}{l}1.26- \\
1.82\end{array}$ & $1.25^{*}$ & $\begin{array}{l}1.03- \\
1.51\end{array}$ & 1.21 & $\begin{array}{l}0.94- \\
1.55\end{array}$ & 1.11 & $\begin{array}{l}0.86- \\
1.44 \\
\end{array}$ \\
\hline \multicolumn{9}{|c|}{ Model 3 (both sexes): interactions } \\
\hline $\begin{array}{l}\text { Partner status } \\
\text { \# sex }\end{array}$ & \multicolumn{8}{|c|}{$p$-value 0.160} \\
\hline Children \# sex & \multicolumn{8}{|c|}{$p$-value 0.529} \\
\hline $\begin{array}{l}\text { Age of the } \\
\text { youngest child } \\
\text { \# sex }\end{array}$ & \multicolumn{8}{|c|}{$p$-value 0.709} \\
\hline
\end{tabular}

Significance level of interactions of partner status and children with sex

OR presented from the models without interactions. Model 1 controlled for age, region, SRH, and health limitations. Model 2 and 3 controlled for age, region, SRH, health limitations, SES, and employment status. $* p<0.05 ; * * p<0.01 ; * * * p<0.001$

employment status (Model 2) led to significance in the relationship between age of the youngest children and physical activity in men: fathers living with a child aged 7-10 years showed lower odds of physical activity than did fathers living with younger or older children. The comparison between Model 1 and Model 2 showed no other mediating effects of SES and employment status. Analysis of the interaction terms (Model 3) showed no significant differences between mothers and fathers in the associations of physical activity with partner status, number of children, or the age of the youngest child. 
Table 9 Odds ratios (OR) for low physical activity in mothers and fathers, two models compared

\begin{tabular}{|c|c|c|c|c|c|c|c|c|}
\hline \multirow[b]{3}{*}{ Variable } & \multicolumn{4}{|c|}{ Mothers } & \multicolumn{4}{|c|}{ Fathers } \\
\hline & \multicolumn{2}{|c|}{ Model 1} & \multicolumn{2}{|c|}{ Model 2} & \multicolumn{2}{|c|}{ Model 1} & \multicolumn{2}{|c|}{ Model 2} \\
\hline & OR & $\begin{array}{l}95 \% \\
\text { CI }\end{array}$ & OR & $\begin{array}{l}95 \% \\
\text { CI }\end{array}$ & OR & $\begin{array}{l}95 \% \\
\mathrm{CI}\end{array}$ & OR & $\begin{array}{l}95 \% \\
\text { CI }\end{array}$ \\
\hline \multicolumn{9}{|c|}{ Partner status } \\
\hline Single & 1.07 & $\begin{array}{l}0.78- \\
1.46\end{array}$ & 1.18 & $\begin{array}{l}0.85- \\
1.62 \\
\end{array}$ & 0.67 & $\begin{array}{l}0.27- \\
1.65\end{array}$ & 0.57 & $\begin{array}{l}0.21- \\
1.59 \\
\end{array}$ \\
\hline Married & 1 & & 1 & & 1 & & 1 & \\
\hline Divorced & $0.68 * *$ & $\begin{array}{l}0.54- \\
0.86\end{array}$ & $0.74 *$ & $\begin{array}{l}0.59- \\
0.94\end{array}$ & 0.95 & $\begin{array}{l}0.51- \\
1.79 \\
\end{array}$ & 1.06 & $\begin{array}{l}0.54- \\
2.07\end{array}$ \\
\hline
\end{tabular}

Number of children

\begin{tabular}{l|l|l|l|l|l|l|l|l}
\hline 1 & 1 & & 1 & & 1 & & 1 & \\
\hline 2 & 1.02 & $0.87-$ & 1.00 & $0.85-$ & 0.96 & $0.76-$ & 0.97 & $0.77-$ \\
& & 1.21 & & 1.18 & & 1.22 & & 1.23 \\
\hline $3+$ & $0.67 * *$ & $0.53-$ & $0.72 * *$ & $0.56-$ & 0.93 & $0.65-$ & 1.06 & $0.73-$ \\
& & 0.85 & & 0.91 & & 1.32 & & 1.53 \\
\hline
\end{tabular}

Age of the youngest child in the household

\begin{tabular}{l|l|l|l|l|l|l|l|l}
\hline $0-6$ & 1 & & 1 & & 1 & & 1 & \\
\hline $7-10$ & 0.98 & $0.80-$ & 1.02 & $0.83-$ & 1.29 & $0.97-$ & $1.36^{*}$ & $1.01-$ \\
& & 1.20 & & 1.25 & & 1.72 & & 1.82 \\
\hline $11+$ & 0.93 & $0.76-$ & 1.01 & $0.81-$ & 0.84 & $0.63-$ & 0.95 & $0.70-$ \\
& & 1.15 & & 1.25 & & 1.13 & & 1.27 \\
\hline
\end{tabular}

Model 3 (both sexes): interactions

\begin{tabular}{l|l}
\hline $\begin{array}{l}\text { Partner status } \\
\text { \# sex }\end{array}$ & p-value 0.213 \\
\hline $\begin{array}{l}\text { Children \# } \\
\text { sex }\end{array}$ & p-value 0.135 \\
\hline $\begin{array}{l}\text { Age of the } \\
\text { youngest } \\
\text { child \# sex }\end{array}$ & p-value 0.184 \\
\hline
\end{tabular}

Significance level of interactions of partner status and children with sex

OR presented from the models without interactions. Model 1 controlled for age, region, SRH, and health limitations. Model 2 and 3 controlled for age, region, SRH, health limitations, SES, and employment status. $* p<0.05 ; * p<0.01 ; * * p<0.001$

\section{Discussion}

The four health-risk behaviours in the current study were found to be differently associated with partnership and parenthood. The association of partnership and parenthood with health behaviour is not homogeneous and cannot be explained through only one mechanism, such as social control or social support. The clearly health detrimental behaviours, i.e., smoking and at-risk alcohol consumption, seem to be more strongly associated with partnership and parenthood than are nutrition and physical activity. 
Our work suggests that partner status is strongly associated with smoking in both men and women, irrespective of parenthood, which is consistent with findings from other studies (McDermott et al. 2004; Waldron and Lye 1989). The provision of social support for quitting smoking and the social control against relapse is usually given as the explanation for the positive effect of marriage on smoking (Klein et al. 2013). In our study, we were unable to distinguish the smoking habits of the partner, but results from previous work show that living with a smoker is correlated with relapse of smoking (Kahn et al. 2002) and is a barrier to quitting (McDermott et al. 2006). Thus, the protective effect of marriage may be available only when the partner also does not smoke. The slight correlation between smoking and parenthood (especially of two children) could be understood in the terms of increased responsibility to protect children. According to McDermott et al. (2006), parents have the responsibility to protect children from passive smoking and, as well, of positive role modelling to protect children from becoming smokers themselves. This seems to be valid, particularly for women with young children.

We also found that single men and women have significantly higher at-risk alcohol consumption than do their married counterparts. These results confirm findings of other studies (Hajema and Knibbe 1998; Kuntsche et al. 2006). It has been previously argued that decreased consumption within marriage is likely to be an effect of decreased exposure to situations where drinking is considered appropriate and not an effect of selection within this group (Hajema and Knibbe 1998). Thus, the transition to marriage and parenthood has been seen as a constraint on drinking behaviour (Paradis 2011). Yet in the current study, the association with parenthood was only found in women. Similarly, a strong sex difference in the associations of heavy drinking and social roles was also found in Germany, by Kuntsche et al. (2006) in a comparison of several industrialised countries. Often, social stratification is considered to be more important for men, whereas family roles are more important for women (Kuntsche et al. 2006). Thus, differences between women and men in health behaviours may be primarily a function of differences in the social roles occupied by men and women (Nomaguchi and Bianchi 2004). This could explain the relationship between parenthood and heavy drinking in mothers; however, this seems to be valid only for mothers with at least one preschool-aged child, as mothers with older children also show higher odds of heavy drinking. The constraint of parental roles thus seems to have a relative short-term effect. These results are in line with the suggestion that mothers tend to feel more guilty about going out for drinks because of the social pressure to always be "on call" for their children (Paradis 2011), and this could be especially the case for mothers with preschool-aged children.

We also found a healthy diet to be strongly associated with living with children but independent of the number of children in the household (especially in men). These findings are consistent with findings of previous research (Bassett-Gunter et al. 2013; Condon et al. 2004). It is generally considered that parenthood motivates individuals to eat healthily because parents perceive themselves to be role models for their children (Bassett-Gunter et al. 2013; Patrick and Nicklas 2005). Previous findings that women have less intention to eat healthily with an increase in the 
number of the children in the household (Bassett-Gunter et al. 2013; Hung 2007) could not be confirmed in our analysis; however, in women, there is a relationship with the age of the children in the household. The finding that mothers with older children eat less healthily could mean that role modelling is mainly valid for young children. Another consideration is that fruit and vegetable consumption is only one element of good nutrition - no other dietary measure was available in the dataset (e.g., sugar or fat intake). Yet, Yannakoulia et al. (2008) showed that in relation to marital status, there may be different patterns of healthy dietary behaviour.

With regard to physical activity, we found that mothers are more active than women without children, but a similar difference was not found in men. It is usually considered that parents play a substantial role in the development of physical activity patterns in their children (Gustafson and Rhodes 2006), and in Germany it may be that this role falls under the purview of mothers. Unfortunately, in our analysis, we were unable to differentiate between leisure-time activity and household activity. Other research has shown that with entry to parenthood, leisure-time activity is replaced by household activity because of a change in roles (Candelaria et al. 2012; Grace et al. 2006; Scharff et al. 1999; Sternfeld et al. 1999). As mothers usually engage more often in the care of children, their physical activity related to child-care (e.g., spending time on the playground or carrying the child) may be an important influence lacking in fathers. Sitting time is lower for both mothers and fathers compared with nonparents, but again, this finding is more prevalent among women (Candelaria et al. 2012). This too is likely related to the increased household activity in households with children. A similar argument was given by Burton and Turrell (2000), who concluded that in general, the physical activity of men and women is different and that parenthood may have a greater effect on physical activity in mothers than on fathers. Interestingly, other studies have shown a reduction in physical activity in mothers, especially in mothers of young children (Candelaria et al. 2012; Hull et al. 2010). These contradictory results may have been related to differences in the definition of physical activity (as opposed to sporting activity) and the methods used to measure physical activity.

Returning to our hypothesis on the mediating effect of SES and employment status, we conclude that the associations between health behaviour and family status can be explained to a limited extent by SES and employment status. This is consistent with the finding of Roos et al. (1998) that family status (partnership and parenthood) and structural factors (educational level and employment) are independently associated with nutrition.

Our hypotheses regarding sex differences in the association of family status and health behaviour remain unconfirmed-sex differences are not as strong as expected. Contrary to previous findings (Umberson 1992), we found no sex differences in the relation of partner status with any health behaviour. This could be attributable to changes in social roles in Germany in recent decades, as women are now more active in the labour market and men, to some degree, in household activities. Nevertheless, the birth of a child (especially the first) does seem to lead to a return to traditional family patterns (Federal Ministry for Family Affairs, Senior Citizens, Women and Youth 2011), as evidenced by the strong differences in health behaviour seen between women and men living with and without children. Further, 
the relationship between age of the youngest child and health behaviour suggests that during pregnancy and first years of parenthood, women in particular are willing to stop harmful health behaviours, such as smoking and at-risk alcohol consumption but that as children grow, this willingness seems to decrease (Waldron and Lye 1989). Longitudinal studies are needed to validate this hypothesis.

\section{Strength and Limitations}

The strength of our study was the use of a large sample that was representative of the German population. The size of the sample allowed the study of specific subgroups. Also, the large set of indicators included in the GEDA survey allowed a deep analysis.

The main limitation of our analysis was our reliance on cross-sectional data. This means that we were unable to study changes over time or to make inferences about causality in the relationship between health behaviour and partner and parental status. Thus, it could be that partnership and parenthood influence health behaviour (causality) and that health behaviour also influences the partnership and parenthood experience (selectivity) (Hank and Steinbach in this book), but this will have to be investigated elsewhere. Another limitation is that the data on health behaviour were self-reported and therefore subject to social desirability bias. This may have been truer for women and men with children than for those living without children, especially regarding smoking and at-risk alcohol consumption. Finally, we only had data on parents with children living in the household, and therefore our findings reflect only these parents - parents who were not living with their children (because of a separation/divorce or after leaving the parental home) could not be identified in our data.

\section{Further Research}

A further step would be to test the moderating effects of SES and employment status. We were unable to do this with our data because of the relatively low number of cases, especially for lone fathers. Future research should also include diverse populations (for instance immigrants) in order to investigate the relationship between family status and health behaviour within different demographic groups. Furthermore, international comparisons, using the same or similar outcome and predictor variables, are needed to understand the potential variations between the different welfare states and social settings (see Hank and Steinbach in this volume). In addition, there is a need for trend analysis to explore possible changes in the association of health behaviour with family roles over time. Last but not least, only analyses with longitudinal data offer the possibility of investigating selection and causality effects in the association between health behaviour and partner and parental status. 


\section{Conclusion}

Understanding the associations between family status and health behaviour can help the identification of appropriate target groups for health promotion and prevention programs, to support healthy lifestyle at all life stages. Both partnership and, especially, parenthood positively correlate with most of the studied health behaviours. In particular, the period around pregnancy, birth, and the first years with a child seems to be a 'teachable moment' during which women are willing to change their behaviour (McBride et al. 2003); however this beneficial effect on health behaviour seems to be temporary. This knowledge suggests that health agencies should develop policies and programs to support the maintenance of healthy behaviour in women after their children have grown or have left the household, or after disruption of a partnership. Furthermore, a more gender-equal focus in health promotion might increase men's involvement in lifestyle change (Edvardsson et al. 2011).

\section{References}

Abel, T., McQueen, D. V., Backen, K., \& Currie, C. (1992). Patterns of unhealthy eating behaviours in a middle aged Scottish Population. Scottish Medical Journal, 37(6), 170-174. https://doi.org/10.1177/003693309203700604.

Ajzen, I. (1991). The theory of planned behavior. Organizational Behaviour and Human Decision Processes, 50(2), 179-211. https://doi.org/10.1016/0749-5978(91)90020-T.

Anderson, A. S., Macintyre, S., \& West, P. (1994). Dietary patterns among adolescents in the west of Scotland. British Journal of Nutrition, 71, 111-122.

Backett, K. C., \& Davison, C. (1995). Lifecourse and lifestyle: The social and cultural location of health behaviours. Social Science \& Medicine, 40(5), 629-638. https://doi.org/10.1016/02779536(95)80007-7.

Bassett-Gunter, R. L., Levy-Milne, R., Naylor, P. J., Symons Downs, D., Benoit, C., Warburton, D. E. R., et al. (2013). Oh baby! motivation for healthy eating during parenthood transitions: A longitudinal examination with a theory of planned behavior perspective. International Journal of Behavioral Nutrition and Physical Activity, 10, 88.

Bellows-Riecken, K. H., \& Rhodes, R. E. (2008). A birth of inactivity? A review of physical activity and parenthood. Preventive Medicine, 46(2), 99-110. https://doi.org/10.1016/j.ypmed. 2007.08.003.

Berge, J. M., Larson, N., Bauer, K. W., \& Neumark-Sztainer, D. (2011). Are parents of young children practicing healthy nutrition and physical activity behaviors? Pediatrics, 127(5), 881887. https://doi.org/10.1542/peds.2010-3218.

Bottorff, J. L., Oliffe, J., Kalaw, C., Carey, J., \& Mroz, L. (2006). Men's constructions of smoking in the context of women's tobacco reduction during pregnancy and postpartum. Social Science \& Medicine, 62(12), 3096-3108. https://doi.org/10.1016/j.socscimed.2005.11.058.

Brenner, H., \& Mielck, A. (1993). Children's exposure to parental smoking in West Germany. International Journal of Epidemiology, 22(5), 818-823. https://doi.org/10.1093/ije/22.5.818.

Brockmann, H., \& Klein, T. (2004). Love and death in Germany: The marital biography and its effect on mortality. Journal of Marriage and Family, 66(3), 567-581.

Brown, W. J., Heesch, K. C., \& Miller, Y. D. (2009). Life events and changing physical activity patterns in women at different life stages. Annals of Behavioral Medicine, 37(3), 294-305. https://doi.org/10.1007/s12160-009-9099-2. 
Burke, V., Giangiulio, N., Gillam, H. F., Beilin, L. J., Houghton, S., \& Milligan, R. A. K. (1999). Health promotion in couples adapting to a shared lifestyle. Health Education Research, 14(2), 269-288. https://doi.org/10.1093/her/14.2.269.

Burton, N. W., \& Turrell, G. (2000). Occupation, hours worked, and leisure-time physical activity. Preventive Medicine, 31(6), 673-681. https://doi.org/10.1006/pmed.2000.0763.

Bush, K., Kivlahan, D. R., McDonell, M. B., Fihn, S. D., Bradley, K. A., \& for the Ambulatory Care Quality Improvement, P. (1998). The audit alcohol consumption questions (audit-c): An effective brief screening test for problem drinking. Archives of Internal Medicine, 158(16), 1789-1795. https://doi.org/10.1001/archinte.158.16.1789.

Candelaria, J. I., Sallis, J. F., Conway, T. L., Saelens, B. E., Frank, L. D., \& Slymen, D. J. (2012). Differences in physical activity among adults in households with and without children. Journal of Physical Activity and Health, 9(7), 985-995.

Condon, J. T., Boyce, P., \& Corkindale, C. J. (2004). The first-time fathers study: A prospective study of the mental health and wellbeing of men during the transition to parenthood. Australian and New Zealand Journal of Psychiatry, 38(1-2), 56-64.

DiClemente, C. C., Dolan-Mullen, P., \& Windsor, R. A. (2000). The process of pregnancy smoking cessation: Implications for interventions. Tobacco Control, 9(suppl 3), iii16-iii21. https://doi.org/10.1136/tc.9.suppl_3.iii16.

Edvardsson, K., Ivarsson, A., Eurenius, E., Garvare, R., Nystrom, M. E., Small, R., et al. (2011). Giving offspring a healthy start: Parents' experiences of health promotion and lifestyle change during pregnancy and early parenthood. BMC Public Health, 11, 936. https://doi.org/10.1186/ 1471-2458-11-936.

EHEMU. (2010). European Health Expectancy Monitoring Unit. The Minimum European Health Module.

Eng, P. M., Kawachi, I., Fitzmaurice, G., \& Rimm, E. B. (2005). Effects of marital transitions on changes in dietary and other health behaviours in US male health professionals. Journal of Epidemiology and Community Health, 59(1), 56-62. https://doi.org/10.1136/jech.2004.020073.

Esping-Andersen, G. (1990). The three worlds of welfare capitalism. Princeton, NJ: Princeton University Press.

Federal Ministry for Family Affairs Senior Citizens Women and Youth (Ed.). (2011). Neue Wege-Gleiche Chancen. Gleichstellung von Frauen und Männern im Lebensverlauf. Erster Gleichstellungbericht [New ways-Equal chances. Equal treatment of women and men in life-course perspektive. First report on equality of treatment]. Berlin: Federal Ministry for Family Affairs, Senior Citizens, Women and Youth.

Food and Agriculture Organization. (2004). Joint FAO/WHO Workshop on Fruit and Vegetables for Health (September 1-3, 2004; Kobe, Japan). Retrieved from http://www.who.int/ dietphysicalactivity/publications/fruit_vegetables_report.pdf?ua $=1$.

Fuller, T. D. (2010). Relationship status, health, and health behavior: An examination of cohabiters and commuters. Sociological Perspectives, 53(2), 221-246.

Gabler, S., \& Häder, S. (1999). Generierung von Telefonstichproben mit TelSuSa [Generating telephone samples using TelSuSa]. ZUMA-Nachrichten, 44, 138-143.

Gerlach, I. (2008). Sozialstaatskonzeptionen und Familienpolitik. In Bundeszentrale für politische Bildung (Ed.), Informationen zur politischen Bildung (Heft 301): Familie und Familienpolitik. Bonn: Bundeszentrale für politische Bildung.

Grace, S., Williams, A., Stewart, D., \& Franche, R. (2006). Healthpromoting behaviours through pregnancy, maternity leave, and return to work: Effects of role spillover and other correlates. Women and Health, 43, 51-71.

Gual, A., Segura, L., Contel, M., Heather, N., \& Colom, J. (2002). AUDIT-3 and AUDIT-4: Effectiveness of two short forms of the alcohol use disorders identification test. Alcohol and Alcoholism, 37(6), 591-596. https://doi.org/10.1093/alcalc/37.6.591.

Gustafson, S., \& Rhodes, R. (2006). Parental correlates of physical activity in children and early adolescents. Sports Medicine, 36(1), 79-97. https://doi.org/10.2165/00007256-20063601000006 . 
Hajema, K.-J., \& Knibbe, R. A. (1998). Changes in social roles as predictors of changes in drinking behaviour. Addiction, 93(11), 1717-1727. https://doi.org/10.1046/j.1360-0443.1998. 931117179.x.

Hull, E. E., Rofey, D. L., Robertson, R. J., Nagle, E. F., Otto, A. D., \& Aaron, D. J. (2010). Influence of marriage and parenthood on physical activity: A 2-year prospective analysis. Journal of Physical Activity \& Health, 7(5), 577-583.

Hung, C. (2007). The psychosocial consequences for primiparas and multiparas. Kaohsiung Journal of Medical Sciences, 23, 352-360.

Kahn, R. S., Certain, L., \& Whitaker, R. C. (2002). A reexamination of smoking before, during, and after pregnancy. American Journal of Public Health, 92(11), 1801-1808. https://doi.org/ 10.2105/AJPH.92.11.1801.

Kaplan, M. S., Newsom, J. T., McFarland, B. H., \& Lu, L. (2001). Demographic and psychosocial correlates of physical activity in late life. American Journal of Preventive Medicine, 21(4), 306-312. https://doi.org/10.1016/S0749-3797(01)00364-6.

King, A., Kiernan, M., Ahn, D., \& Wilcox, S. (1998). The effects of marital transitions on changes in physical activity: Results from a 10-year community study. Annals of Behavioral Medicine, 20(2), 64-69. https://doi.org/10.1007/BF02884450.

Klein, T., Rapp, I., \& Schneider, B. (2013). The influence of couples' living arrangements on smoking habits and body weight. Comparative Population Studies-Zeitschrift für Bevölkerungswissenschaft, 38(3), 673-694.

Kuntsche, S., Gmel, G., Knibbe, R. A., Kuendig, H., Bloomfield, K., Kramer, S., et al. (2006). Gender and cultural differences in the association between family roles, social stratification, and alcohol use: A European cross-cultural analysis. Alcohol and Alcoholism, 41(suppl 1), i37i46. https://doi.org/10.1093/alcalc/agl074.

Kuntsche, S., Knibbe, R. A., \& Gmel, G. (2009). Social roles and alcohol consumption: A study of 10 industrialised countries. Social Science and Medicine, 68(7), 1263-1270.

Lampert, T., Kroll, L., Müters, S., \& Stolzenberg, H. (2013). Messung des sozioökonomischen Status in der Studie "Gesundheit in Deutschland aktuell" (GEDA). Bundesgesundheitsbl, 56, 131-143.

Lange, C., Jentsch, F., Allen, J., Hoebel, J., Kratz, A. L., von der Lippe, E., et al. (2015). Data resource profile: German health update (GEDA) - The health interview survey for adults in Germany. International Journal of Epidemiology. https://doi.org/10.1093/ije/dyv067.

McBride, C. M., Emmons, K. M., \& Lipkus, I. M. (2003). Understanding the potential of teachable moments: The case of smoking cessation. Health Education Research, 18(2), 156-170. https:// doi.org/10.1093/her/18.2.156.

McDermott, L., Dobson, A., \& Owen, N. (2006). From partying to parenthood: Young women's perceptions of cigarette smoking across life transitions. Health Education Research, 21(3), 428-439. https://doi.org/10.1093/her/cyl041.

McDermott, L., Dobson, A., \& Russell, A. (2004). Changes in smoking behaviour among young women over life stage transitions. Australian \& New Zealand Journal of Public Health, 28(4), 330-335. https://doi.org/10.1111/j.1467-842X.2004.tb00439.x.

McIntyre, C. A., \& Rhodes, R. E. (2009). Correlates of leisure-time physical activity during transitions to motherhood. Women Health, 49(1), 66-83. https://doi.org/10.1080/ 03630240802690853.

Nomaguchi, K. M., \& Bianchi, S. M. (2004). Exercise time: Gender differences in the effects of marriage, parenthood, and employment. Journal of Marriage and Family, 66(2), 413-430. https://doi.org/10.1111/j.1741-3737.2004.00029.x.

Olson, C. M. (2005). Tracking of food choices across the transition to motherhood. Journal of Nutrition Education and Behavior, 37(3), 129-136. https://doi.org/10.1016/S1499-4046(06) 60267-4.

Paradis, C. (2011). Parenthood, drinking locations and heavy drinking. Social Science and Medicine, 72(8), 1258-1265.

Patrick, H., \& Nicklas, T. A. (2005). A review of family and social determinants of children's eating patterns and diet quality. Journal of the American College of Nutrition, 24(2), 83-92. 
Rapp, I., \& Schneider, B. (2014). Unterscheiden sich Partnerschaftseffekte auf die Sportaktivität nach dem Gesundheitszustand? In S. Becker (Ed.), Aktiv und Gesund? (pp. 379-391). Wiesbaden: Springer Fachmedien Wiesbaden.

Reinert, D. F., \& Allen, J. P. (2007). The alcohol use disorders identification test: An update of research findings. Alcoholism: Clinical and Experimental Research, 31(2), 185-199. https:// doi.org/10.1111/j.1530-0277.2006.00295.x.

Robert Koch Institute (Ed.). (2011). Daten und Fakten: Ergebnisse der Studie «Gesundheit in Deutschland aktuell 2009» [Data and facts: Results of the "German Health Update» study 2009]. Beiträge zur Gesundheitsberichterstattung des Bundes. Berlin: Robert Koch Institute.

Robert Koch Institute (Ed.). (2012). Daten und Fakten: Ergebnisse der Studie "Gesundheit in Deutschland aktuell 2010» [Data and facts: Results of the «German Health Update» study 2010]. Beiträge zur Gesundheitsberichterstattung des Bundes. Berlin: Robert Koch Institute.

Roos, E., Lahelma, E., Virtanen, M., Prättälä, R., \& Pietinen, P. (1998). Gender, socioeconomic status and family status as determinants of food behaviour. Social Science and Medicine, 46 (12), 1519-1529.

Scharff, D. P., Homan, S., Kreuter, M., \& Brennan, L. (1999). Factors associated with physical activity in women across the life span: Implications for program development. Women Health, 29(2), 115-134. https://doi.org/10.1300/J013v29n02_08.

Sternfeld, B., Ainsworth, B. E., \& Quesenberry, C. P., Jr. (1999). Physical activity patterns in a diverse population of women. Preventive Medicine, 28(3), 313-323. https://doi.org/10.1006/ pmed.1998.0470.

Umberson, D. (1987). Family status and health behaviors: Social control as a dimension of social integration. Journal of Health and Social Behavior, 28(3), 306-319.

Umberson, D. (1992). Gender, marital status and the social control of health behavior. Social Science and Medicine, 34(8), 907-917.

Umberson, D., Crosnoe, R., \& Reczek, C. (2010). Social relationships and health behavior across the life course. Annual Review of Sociology, 36(1), 139-157. https://doi.org/10.1146/annurevsoc-070308-120011.

Waldron, I., \& Lye, D. (1989). Family roles and smoking. American Journal of Preventive Medicine, 5(3), 136-141.

White, C., Oliffe, J. L., \& Bottorff, J. L. (2012). Fatherhood, smoking, and secondhand smoke in North America: An historical analysis with a view to contemporary practice. American Journal of Men's Health, 6(2), 146-155. https://doi.org/10.1177/1557988311425852.

Yannakoulia, M., Panagiotakos, D., Pitsavos, C., Skoumas, Y., \& Stafanadis, C. (2008). Eating patterns may mediate the association between marital status, body mass index, and blood cholesterol levels in apparently healthy men and women from the ATTICA study. Social Science \& Medicine, 66(11), 2230-2239. https://doi.org/10.1016/j.socscimed.2008.01.051.

Open Access This chapter is licensed under the terms of the Creative Commons Attribution 4.0 International License (http://creativecommons.org/licenses/by/4.0/), which permits use, sharing, adaptation, distribution and reproduction in any medium or format, as long as you give appropriate credit to the original author(s) and the source, provide a link to the Creative Commons license and indicate if changes were made.

The images or other third party material in this chapter are included in the chapter's Creative Commons license, unless indicated otherwise in a credit line to the material. If material is not included in the chapter's Creative Commons license and your intended use is not permitted by statutory regulation or exceeds the permitted use, you will need to obtain permission directly from the copyright holder.

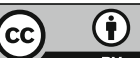

